\title{
Acolbifene Hydrochloride
}

National Cancer Institute

\section{Source}

National Cancer Institute. Acolbifene Hydrochloride. NCI Thesaurus. Code C65213.

The hydrochloride salt form of acolbifene, a fourth-generation estrogen receptor modulator (SERM) with potential lipid lowering and antineoplastic activity. Acolbifene specifically binds to estrogen receptors in responsive tissue, including liver, bone, breast, and endometrium. The resulting lig and-receptor complex is translocated to the nucleus where, depending on the tissue type, it promotes or suppresses the transcription of estrogen-regulated genes, thereby exerting its agonistic or antagonistic effects. Acolbifene acts as an estrogen antagonist in uterine and breast tissue, thereby blocking the effects of estrogen in these tissues. This may inhibit tumor cell proliferation in ERpositive tumor cells. This agent functions as an estrogen agonist in lipid metabolism, thereby decreasing total and LDL cholesterol levels. In bone, it decreases bone resorption and bone turnover and increases bone mineral density. 